A. C. Heijboer - A. M. van den Hoek • H. Pijl •

P. J. Voshol · L. M. Havekes · J. A. Romijn •

E. P. M. Corssmit

\title{
Intracerebroventricular administration of melanotan II increases insulin sensitivity of glucose disposal in mice
}

Received: 26 November 2004 / Accepted: 26 February 2005 / Published online: 22 June 2005

(C) Springer-Verlag 2005

\begin{abstract}
Aims/hypothesis: The present study was conducted to evaluate the effects of central administration of melanotan II (MTII), a melanocortin-3/4 receptor agonist, on hepatic and whole-body insulin sensitivity, independent of food intake and body weight. Methods: Over a period of $24 \mathrm{~h}, 225 \mathrm{ng}$ of MTII was injected in three aliquots into the left lateral ventricle of male $\mathrm{C} 57 \mathrm{Bl} / 6$ mice. The animals had no access to food. The control group received three injections of distilled water. Whole-body and hepatic insulin sensitivity were measured by hyperinsulinaemiceuglycaemic clamp in combination with $\left[{ }^{3} \mathrm{H}\right]$ glucose infusion. Glut4 mRNA expression was measured in skeletal muscle. Results: Plasma glucose and insulin concentrations under basal and hyperinsulinaemic conditions were similar in MTII- and placebo-treated mice. Endogenous glucose production (EGP) and glucose disposal in the basal state were significantly higher in MTII-treated mice than in the control group $\left(71 \pm 22\right.$ vs $43 \pm 12 \mu \mathrm{mol} \cdot \mathrm{min}^{-1} \cdot \mathrm{kg}^{-1}, p<$ $0.01)$. During hyperinsulinaemia, glucose disposal was significantly higher in MTII-treated mice $(151 \pm 20$ vs $108 \pm 20$ $\left.\mu \mathrm{mol} \cdot \mathrm{min}^{-1} \cdot \mathrm{kg}^{-1}, p<0.01\right)$. In contrast, the inhibitory ef-
\end{abstract}

A. C. Heijboer $(\bowtie) \cdot$ A. M. van den Hoek · H. Pijl ·

P. J. Voshol - J. A. Romijn - E. P. M. Corssmit

Department of Endocrinology and Metabolic Diseases, Leiden University Medical Center,

P.O. Box 9600, 2300 RC Leiden, The Netherlands

e-mail: a.c.heijboer@lumc.nl

Tel.: +31-71-5263082

Fax: $+31-71-5248136$

A. C. Heijboer · A. M. van den Hoek · P. J. Voshol ·

L. M. Havekes

Gaubius Laboratory, TNO-Quality of Life,

Leiden, The Netherlands

L. M. Havekes

Department of Cardiology,

Leiden University Medical Center,

Leiden, The Netherlands

L. M. Havekes

Department of General Internal Medicine,

Leiden University Medical Center,

Leiden, The Netherlands fect of insulin on EGP was not affected by MTII (relative decrease in EGP: $45 \pm 27$ vs $50 \pm 20 \%$ ). Glut4 mRNA expression in skeletal muscle was significantly increased in MTII-treated mice $(307 \pm 94$ vs $100 \pm 56 \%, p<0.01)$. Conclusions/interpretation: Intracerebroventricular administration of MTII acutely increases insulin-mediated glucose disposal but does not affect the capacity of insulin to suppress EGP in C57Bl/6 mice. These data indicate that central stimulation of melanocortin-3/4 receptors modulates insulin sensitivity in a tissue-specific manner, independent of its well-known impact on feeding and body weight.

Keywords Brain - Diabetes - Glut4 - Insulin resistance · Metabolism $\cdot$ Neuropeptides

Abbreviations AgRP: Agouti-related protein - EGP: endogenous glucose production - GAPDH: glyceraldehyde-3-phosphate dehydrogenase $\cdot$ HPA: hypothalamo-pituitary-adrenal axis - icv: intracerebroventricular $\cdot \mathrm{MC}$ : melanocortin $\cdot \alpha-\mathrm{MSH}$ : alpha-melanocyte stimulating hormone $\cdot$ MTII: melanotan II - NPY: neuropeptide Y P POMC: pro-opiomelanocortin

\section{Introduction}

The hypothalamus integrates a multitude of behavioural and metabolic adaptations to food intake and starvation, necessary to maintain fuel homeostasis despite profound environmental variations in nutrient availability [1]. Two types of neuron in the arcuate nucleus of the hypothalamus are of major importance for the control of these processes: neurons co-expressing Agouti-related protein (AgRP) and neuropeptide Y (NPY), and neurons expressing pro-opiomelanocortin (POMC), the molecular precursor of alphamelanocyte-stimulating hormone ( $\alpha$-MSH) [2]. $\alpha$-MSH binds to and stimulates melanocortin (MC) receptors. AgRP can bind to $\mathrm{MC}$ receptors as well, thereby inhibiting the POMC pathway [3]. NPY and POMC neuropeptides exert opposing effects on food intake and fuel homeostasis. NPY 
acts to promote anabolic pathways, whereas $\alpha$-MSH counteracts the effects of NPY [4-6]. For instance, during food deprivation, NPY/AgRP neuronal activity is high while $\mathrm{POMC} / \alpha$-MSH expression levels are low [5], and this setting of the arcuate neuronal circuitry strongly stimulates food intake and reduces energy expenditure [7].

Apart from its impact on food intake, intracerebroventricular (icv) administration of NPY acutely hampers the capacity of insulin to inhibit hepatic glucose and VLDL production in $\mathrm{C} 57 \mathrm{Bl} / 6$ mice, while insulin sensitivity of muscle and adipose tissue remains unaffected [8]. Conversely, chronic (7 days) icv infusion of $\alpha$-MSH enhances peripheral and hepatic insulin sensitivity in rats through stimulation of the MC3/4 receptor [9], and POMC gene overexpression ameliorates insulin resistance in leptindeficient mice independently of its effects on food intake and body weight [10]. In the latter studies, the effects on insulin sensitivity occur in the presence of a concomitant reduction in food intake and fat mass, which precludes distinction between putative direct effects of $\alpha$-MSH or $\mathrm{MC} 4$ receptor on insulin sensitivity and indirect effects via feeding and body composition.

In addition to the effect of MC4 receptor activation on insulin sensitivity, decreased insulin concentration after central activation of the melanocortin neuronal circuitry, and increased levels of insulin in MC4 receptor knock-out mice even before the onset of detectable hyperphagia or obesity [11], have been documented. In humans, MC4 receptor mutations are associated with obesity $[12,13]$.

The aim of the present study was to document the direct effects of the activation of MC3/4 receptors on insulin sensitivity (i.e. via mechanistic routes other than feeding and fat mass). As such, we injected (icv) melanotan II (MTII) [14], an agonist of the MC3/4 receptor [15], and quantified hepatic and peripheral insulin sensitivity of glucose metabolism during a hyperinsulinaemic-euglycaemic clamp in mice with no access to food.

\section{Materials and methods}

Animals Male 3-month-old C57Bl/6 mice (originating from The Jackson Laboratory [Bar Harbor, ME, USA] and bred in our own animal facility) were housed in a temperatureand humidity-controlled room on a 12-h light-dark cycle with free access to standard mouse chow and water. All animal experiments were performed in accordance with the principles of laboratory animal care and regulations of Dutch law on animal welfare, and the protocol was approved by the institutional ethics committee for animal procedures.

Surgical procedures Mice were anaesthetised with $0.5 \mathrm{mg} /$ $\mathrm{kg}$ medetomidine (Pfizer, Capelle a/d IJssel, The Netherlands), $5 \mathrm{mg} / \mathrm{kg}$ midazolam (Roche, Mijdrecht, The Netherlands) and $0.05 \mathrm{mg} / \mathrm{kg}$ fentanyl (Janssen-Cilag, Tilburg, The Netherlands). A 25-gauge guide cannula was stereotactically implanted into the left lateral ventricle using the following coordinates from Bregma: $0.46 \mathrm{~mm}$ posterior,
$1.0 \mathrm{~mm}$ lateral end, $2.2 \mathrm{~mm}$ ventral [16]. The guide cannula was secured to the skull surface using two screws and dental cement (AgnTho's, Lidingö, Sweden). After a recovery period of 1 week, adequate placement of the cannulae was tested by measuring the feeding response to an acute icv injection of NPY $(5 \mu \mathrm{g}$ dissolved in $1 \mu \mathrm{l}$ sterile water; Bachem, Bubendorf, Germany).

Hyperinsulinaemic-euglycaemic clamp Mice fasted for $24 \mathrm{~h}$ (with food withdrawn at 09.00 hours on the day before the experiment) were used. At 9.00 and 17.00 hours on the day before the experiment and at 08.45 hours on the day of the experiment mice were given $75 \mathrm{ng}$ (in $1.5 \mu \mathrm{l}$ distilled water) MTII (PhoenixEurope, Karlsruhe, Germany) or $1.5 \mu \mathrm{l}$ distilled water (control group) icv. The dose of MTII was based on data from a study by Murphy et al. [17], which showed inhibition of food intake using this dose. During icv injections, mice were lightly anaesthetised with isoflurane. All experiments were performed at 09.00 hours. Hyperinsulinaemic-euglycaemic clamps were performed as described previously $[18,19]$. During the experiments, mice were sedated with $6.25 \mathrm{mg} / \mathrm{kg}$ acepromazine (Sanofi sante animale, Libourne Cedex, France), $6.25 \mathrm{mg} / \mathrm{kg} \mathrm{mi}-$ dazolam (Roche) and $0.3125 \mathrm{mg} / \mathrm{kg}$ fentanyl (JanssenCilag).

Basal rates of glucose turnover were measured by giving a primed $(26 \mathrm{kBq})$ continuous $(44 \mathrm{kBq} / \mathrm{h})$ infusion of $\left[{ }^{3} \mathrm{H}\right]$ glucose (Amersham, Little Chalfont, UK) for $80 \mathrm{~min}$. Subsequently, insulin was administered in a primed $(4.1 \mathrm{mU})$ continuous $(6.8 \mathrm{mU} / \mathrm{h})$ i.v. infusion for 2 to $3 \mathrm{~h}$ to attain steady-state circulating insulin levels of about $4 \mathrm{ng} / \mathrm{ml}$. The $\left[{ }^{3} \mathrm{H}\right]$ glucose infusion $(44 \mathrm{kBq} / \mathrm{h})$ was continued. A variable infusion of $12.5 \%$ D-glucose (in PBS) solution was also started and adjusted to maintain blood euglycaemia (measured at 10-min intervals via tail bleeding; Freestyle, TheraSense; Disetronic Medical Systems, Vianen, The Netherlands). Blood samples $(60 \mu \mathrm{l})$ were taken during the basal period (after 60 and $80 \mathrm{~min}$ ) and during the clamp period (when glucose levels in the blood were stable, and 20 and 40 min later) for measurement of plasma glucose, NEFAs, insulin and $\left[{ }^{3} \mathrm{H}\right]$ glucose-specific activity.

$m R N A$ expression of Glut4 Real-time RT-PCR was used to measure mRNA expression levels of Glut4 (now known as Slc2a4) in skeletal muscle. Skeletal muscle was extracted from additional groups of mice at 10.30 hours following a 24-h fast and three icv injections with MTII or vehicle (injections at the same time points as in the hyperinsulinaemic-euglycaemic clamp experiment). Muscle was homogenised in $1.2 \mathrm{ml}$ RNA-Bee (Tel-Test, TX, USA) and total RNA was extracted according to the method described by Chomzcinsky and Sacchi [20]. The amount of RNA was determined by spectrophotometry (ND-1000 spectrophotometer; Nanodrop, Wilmington, DE, USA) at a wavelength of $260 \mathrm{~nm}$. The quality was checked using the ratio of absorption at $260 \mathrm{~nm}$ : absorption at $280 \mathrm{~nm}$. Values for complementary DNA (cDNA), out of total RNA, were obtained. For RT-PCR, forward and reverse primers and 
the TaqMan probe were designed from mouse-specific sequence data (Entrez, National Institutes of Health, Bethesda, MD, USA; and Ensembl, Wellcome Trust Sanger Institute, Cambridge, UK) using computer software (Primer Express; Applied Biosystems, Foster City, CA, USA). For each of the genes a Blast Search was done to reveal that sequence homology was obtainable only for the target gene. Forward and reverse primers and the TaqMan probe (5' CCATGAGATCTGAGGCCACA 3'; 5' GTATTTGCC GAAGTTGTAGCCG 3'; 5' CAAGGGCAAGATCATCA TGCACGACC 3') of Glut4 were used. The TaqMan probe was labelled with 5'-6-carboxyfluorescein and 3'-BHQ1. The genes encoding GAPDH (5' VIC and 3' BHQ1; Applied Biosystems) and cyclophilin (5' TET and $3^{\prime}$ BHQ1, 5' CAAATGCTGGACCAAACACAA 3'; 5' GCCATCCAG CCATTCAGTCT 3'; 5' CCGGTTCCCAGTTTTTTATCT GCACTGCC $3^{\prime}$ ) were used as housekeeping genes. PCR amplification was performed in a total reaction volume of $12.5 \mu \mathrm{l}$. The reaction mixture consisted of: (1) qPCR MasterMix (Eurogentec, Seraing, Belgium); (2) the optimal primer and probe concentrations of Glut4 and the endogenous control; (3) nuclease-free water; and (4) cDNA. An identical cycle profile was used for all genes: $50^{\circ} \mathrm{C}$ for $2 \min +95^{\circ} \mathrm{C}$ for $10 \mathrm{~min}+\left[95^{\circ} \mathrm{C}\right.$ for $15 \mathrm{~s}+60^{\circ} \mathrm{C}$ for 1 min $] \times 40$ cycles. Data were analysed using a comparative critical threshold $(\mathrm{Ct})$ method where the amount of target normalised to the amount of endogenous control (genes encoding GAPDH/cyclophilin) and relative to the control sample is given by $2^{-\Delta \Delta C t}$ (Applied Biosystems). All samples were run together allowing relative comparisons of the samples.

Analytical procedures Plasma glucose and NEFA levels were determined using a commercially available kit (Instruchemie, Delfzijl, The Netherlands; Wako Pure Chemical Industries, Osaka, Japan). Plasma insulin and corticosterone concentrations were measured by ELISA (both ALPCO Diagnostics, Windham, NH, USA). For the measurement of plasma $\left[{ }^{3} \mathrm{H}\right]$ glucose, plasma was deproteinised with $20 \%$ trichloroacetic acid, dried to remove water and resuspended in distilled water. Samples were counted using scintillation fluid (Ultima Gold; Packard, Meridien, CT, USA).

Calculations Glucose turnover rate $\left(\mu \mathrm{mol} \cdot \mathrm{min}^{-1} \cdot \mathrm{kg}^{-1}\right)$ was calculated during the basal period and under steady-state clamp conditions as the rate of tracer infusion $(\mathrm{dpm} / \mathrm{min})$ divided by the plasma-specific activity of $\left[{ }^{3} \mathrm{H}\right]$ glucose $(\mathrm{dpm} / \mu \mathrm{mol})$. The ratio was corrected for body weight.

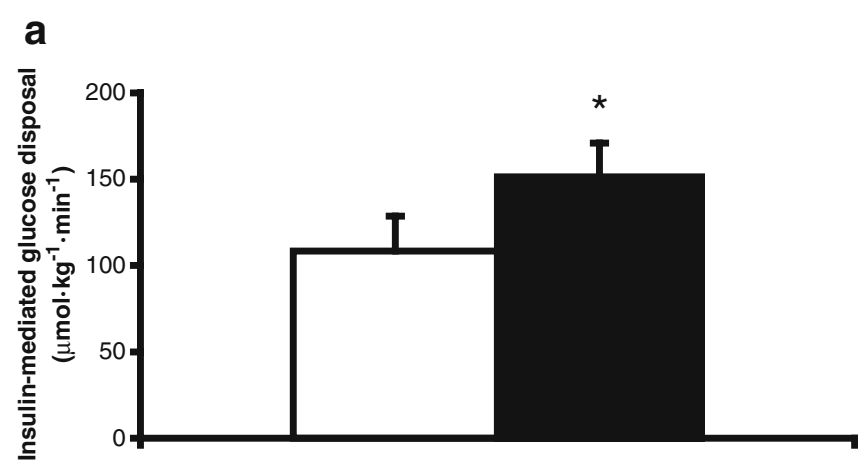

b

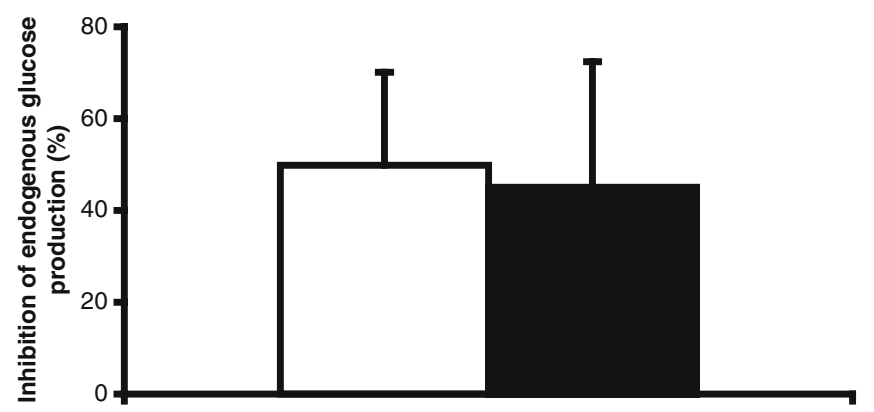

Fig. 1 a Insulin-mediated glucose disposal in mice fasted for $24 \mathrm{~h}$ receiving icv injections of MTII $(n=10$; black bars $)$ or vehicle $(n=8$; white bars). b Inhibition of EGP by insulin in mice fasted for $24 \mathrm{~h}$ receiving icv injections of MTII ( $n=10$; black bars) or vehicle $(n=8$; white bars). Values represent means $\pm \mathrm{SD}$. ${ }^{*} p<0.01$ vs vehicle

Endogenous glucose production (EGP) was calculated as the difference between the tracer-derived rate of glucose appearance and the glucose infusion rate.

Statistical analysis Data are presented as means \pm SD. Differences between groups were determined by the MannWhitney $U$-test for two independent samples. A $p$ value of less than 0.05 was considered statistically significant.

\section{Results}

Plasma parameters Body weight, plasma corticosterone, glucose, NEFA and insulin concentrations under basal and hyperinsulinaemic conditions are shown in Table 1. In the basal state, these parameters did not differ between MTII- and vehicle-treated animals. Under steady-state hyperinsulinaemic conditions, plasma NEFA levels de-
Table 1 Body weight, plasma corticosterone, NEFA, glucose and insulin concentrations in vehicle-treated $(n=10)$ and MTII-treated $(n=8)$ mice

Values are expressed as means $\pm \mathrm{SD}$ $N M$ not measured

\begin{tabular}{lcclll}
\hline & \multicolumn{2}{l}{ Basal conditions } & \multicolumn{2}{l}{ Hyperinsulinaemic conditions } \\
\cline { 2 - 3 } & Vehicle & MTII & & Vehicle & MTII \\
\hline Body weight $(\mathrm{g})$ & $17.9 \pm 1.7$ & $18.9 \pm 1.6$ & - & - \\
Corticosterone $(\mathrm{mmol} / \mathrm{l})$ & $33.3 \pm 17.5$ & $37.8 \pm 12.4$ & $\mathrm{NM}$ & $\mathrm{NM}$ \\
Glucose $(\mathrm{mmol} / \mathrm{l})$ & $5.8 \pm 1.0$ & $6.7 \pm 1.2$ & & $8.4 \pm 1.0$ & $8.2 \pm 2.4$ \\
NEFAs $(\mathrm{mmol} / \mathrm{l})$ & $0.55 \pm 0.17$ & $0.62 \pm 0.17$ & & $0.26 \pm 0.14$ & $0.24 \pm 0.08$ \\
Insulin $(\mathrm{ng} / \mathrm{ml})$ & $0.31 \pm 0.11$ & $0.31 \pm 0.07$ & & $3.8 \pm 2.9$ & $3.7 \pm 2.7$ \\
\hline
\end{tabular}




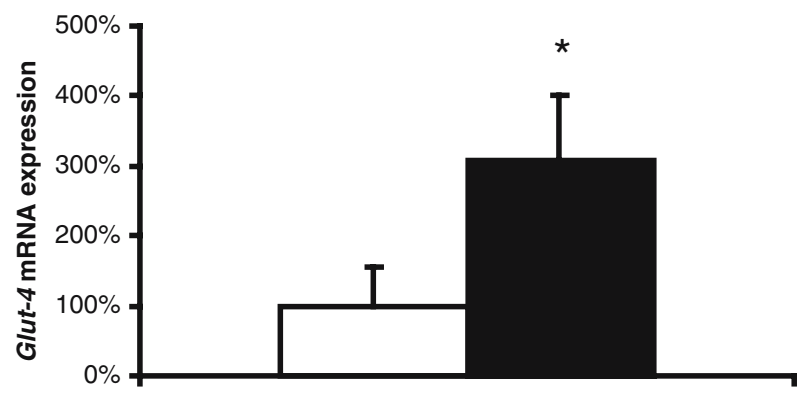

Fig. 2 Glut4 mRNA expression levels in mice fasted for $24 \mathrm{~h}$ receiving injections of MTII ( $n=6$; black bars) or vehicle $(n=7$; white bars) under basal conditions. ${ }^{*} p<0.01$ vs vehicle

creased approximately two-fold and insulin concentrations increased approximately ten-fold as expected. No differences were observed in plasma glucose, insulin and NEFA levels between MTII- and vehicle-treated mice during hyperinsulinaemia.

Glucose turnover Under basal conditions, EGP (and thereby glucose disposal) was significantly higher in MTIItreated animals than in vehicle-treated mice $(71 \pm 22$ vs $43 \pm 10$ $\left.\mu \mathrm{mol} \cdot \mathrm{min}^{-1} \cdot \mathrm{kg}^{-1}, p<0.01\right)$. During the hyperinsulinaemic period, the rate of glucose infusion necessary to maintain euglycaemia was significantly higher in MTII-treated animals than in vehicle-treated animals $(114 \pm 23$ vs $85 \pm 20$ $\left.\mu \mathrm{mol} \cdot \mathrm{min}^{-1} \cdot \mathrm{kg}^{-1}, p<0.05\right)$. Accordingly, the glucose disposal rate was significantly higher in MTII-treated animals $\left(151 \pm 20\right.$ vs $108 \pm 20 \mu \mathrm{mol} \cdot \mathrm{min}^{-1} \cdot \mathrm{kg}^{-1}, p<0.01$; Fig. 1a). In contrast, hyperinsulinaemia suppressed EGP to a similar extent in MTII-treated mice and vehicle-treated mice ( $45 \pm 27$ vs $50 \pm 20 \%$, NS; Fig. 1b).

mRNA expression of Glut4 Glut4 mRNA expression in skeletal muscle was higher in the MTII-treated group than in the vehicle-treated mice ( $307 \pm 94$ vs $100 \pm 56 \%, p<0.01$; Fig. 2).

\section{Discussion}

This study shows that activation of $\mathrm{MC} 3 / 4$ receptors enhances whole-body sensitivity of glucose metabolism for insulin action in mice via mechanisms other than feeding and fat mass. In particular, MTII promotes insulin-mediated glucose disposal but does not affect the capacity of insulin to suppress EGP. These observations are in line with the emerging notion that neural circuits control insulin action in peripheral tissues.

Interestingly, Glut4 mRNA was increased in the muscle of MTII-treated animals, which suggests that activation of MC3/4 receptors enhances Glut4 gene expression to promote glucose uptake. The downstream mechanisms that actuate the effects of hypothalamic neuronal circuits on muscle Glut4 mRNA expression remain to be fully elucidated. The possibility that MTII increases locomotor activity and subsequently Glut4 mRNA expression in muscle cannot be ruled out. However, this seems unlikely since other studies have not observed any increase in locomotor activity following central administration of MTII $[14,17]$. Additional studies are required to elucidate the mechanisms involved in the modulation of insulin sensitivity by central administration of MTII.

Glucose production in the basal state was higher in mice treated with MTII, but MTII did not affect the capacity of insulin to suppress EGP. Thus, central melanocortin pathways appear to directly impact endogenous glucose output. Although Fan et al. [11] reported decreased plasma insulin concentrations after icv administration of MTII, we did not find significant changes in basal plasma insulin concentrations as a potential explanation for the observed increase in basal glucose production. As Fan et al. injected more than ten times the amount we injected, this discrepancy may be explained by the difference in dose. Since MTII has been shown to activate the sympathetic nervous system [21, 22] and sympathetic outflow promotes glucose production [23], it is conceivable that the autonomic nervous system relays signals from the hypothalamus to peripheral tissues to modulate glucose metabolism. Unfortunately, our study does not provide data to evaluate this possibility. Alternatively, the brain could interact with the liver via the hypothalamo-pituitary-adrenal axis (HPA). Corticosteroids stimulate glucose production [24] and HPA activity is under strict control of the hypothalamus. In fact, corticotrophin-releasing hormone neurons in the paraventricular nucleus of the hypothalamus express MC4 receptors, and central MTII injection acutely enhances corticotrophin-releasing hormone and corticosterone release in rats [25]. However, MTII did not modify circulating corticosterone concentrations in our experimental setting, which refutes the hypothesis that central melanocortin pathways modulate the HPA axis to enhance glucose output. Interestingly, short-term fasting is accompanied by a decrease in EGP $[26,27]$, and POMC/ $\alpha$-MSH mRNA expression decreases concomitantly [5]. It is therefore tempting to speculate that blunted melanocortin signalling is involved in the decrease in EGP during fasting. If this was the case, administration of MTII may have prevented the normal decline in EGP associated with fasting in the present study.

Although MTII increased basal EGP, it did not appear to affect the capacity of insulin to suppress it. A previous paper [9] reports that chronic (7 days) icv infusion of $\alpha$ MSH reinforces insulin action on glucose production (as well as on glucose disposal) in rats. However, this effect occurred in the presence of concomitant reductions in food intake, and body adiposity as well as these long-term sequelae of MTII administration can impact on insulin sensitivity. Our data indicate that activation of melanocortin circuits enhances insulin sensitivity independently of food intake and body weight, and that insulin action on glucose disposal is more sensitive to manipulation of MC3/4 receptors than it is capable of suppressing EGP.

We recently showed that icv infusion of NPY in C57B1/6 mice acutely hampers the inhibitory effect of insulin on EGP but does not appear to affect insulin-mediated glucose disposal [8]. We have now shown that activation of melanocortin circuits reinforces insulin action on glucose dis- 
posal but does not affect suppression of glucose production. NPY and melanocortin circuits in the arcuate nucleus play critical roles in the control of fuel homeostasis in the face of fluctuations in nutrient availability. NPY neurons, active during fasting, stimulate feeding and inhibit energy expenditure, whereas melanocortin circuits, suppressed in fasting conditions, counteract NPY to exert opposing effects on energy balance. These behavioural and metabolic actions serve to protect the body against the perils of famine. Our data suggest that the brain also modulates glucose metabolism to further reinforce the line of defence. Enhanced activity of NPY neurons promotes glucose production, but reduced melanocortin activity hampers glucose disposal in fasting conditions, keeping glucose available as pivotal fuel for the brain. Conversely, diminished NPY-ergic signalling and increased melanocortin signalling allow insulin to appropriately suppress glucose output and promote glucose disposal in response to food intake. The current findings may imply that MC-3/4 receptor agonists serve as 'insulin sensitisers' in the treatment of the metabolic syndrome and type 2 diabetes mellitus. However, tachyphylaxis to chronic MTII administration has been observed in mice and rats [28, 29]. In addition, the present study shows that MTII increases basal EGP. Thus, the impact of chronic MTII administration on glucose metabolism in (insulin-resistant) animal models and humans remains to be established.

In conclusion, the present study shows that activation of central melanocortin-3/4 receptors by melanotan II enhances insulin sensitivity in whole-body glucose disposal, independently of food intake and fat mass, but does not affect the ability of insulin to suppress EGP. These observations are in line with the emerging notion that neural circuits, apart from their effects on feeding, modulate insulin sensitivity to adapt metabolic conditions in the face of environmental fluctuations in nutrient availability.

Acknowledgements A.C. Heijboer and A.M. van den Hoek contributed equally to this work.

The research described in the paper was supported by the Dutch Scientific Research Council (project 907-00-002 to E. P. M. Corssmit; 980-10-017 to H. Pijl; 916-36-071 to P. J. Voshol; and 903-39-291 to J. A. Romijn and L. M. Havekes) and the Netherlands Heart Foundation (project 980-10-017 to H. Pijl). This study was conducted within the framework of the 'Leiden Center for Cardiovascular Research LUMCTNO', Leiden, The Netherlands.

\section{References}

1. Schwartz MW, Woods SC, Porte D Jr, Seeley RJ, Baskin DG (2000) Central nervous system control of food intake. Nature 404:661-671

2. Raposinho PD, White RB, Aubert ML (2003) The melanocortin agonist Melanotan-II reduces the orexigenic and adipogenic effects of neuropeptide Y (NPY) but does not affect the NPY-driven suppressive effects on the gonadotropic and somatotropic axes in the male rat. J Neuroendocrinol 15:173-181

3. Nijenhuis WA, Oosterom J, Adan RA (2001) AgRP(83-132) acts as an inverse agonist on the human-melanocortin-4 receptor. Mol Endocrinol 15:164-171
4. Morton GJ, Schwartz MW (2001) The NPY/AgRP neuron and energy homeostasis. Int J Obes Relat Metab Disord 25 [Suppl 5]:S56-S62

5. Hillebrand JJ, de Wied D, Adan RA (2002) Neuropeptides, food intake and body weight regulation: a hypothalamic focus. Peptides 23:2283-2306

6. Wisse BE, Schwartz MW (2001) Role of melanocortins in control of obesity. Lancet 358:857-859

7. Schwartz MW, Woods SC, Seeley RJ, Barsh GS, Baskin DG, Leibel RL (2003) Is the energy homeostasis system inherently biased toward weight gain? Diabetes 52:232-238

8. van den Hoek AM, Voshol PJ, Karnekamp BN et al (2004) Intracerebroventricular neuropeptide $\mathrm{Y}$ infusion precludes inhibition of glucose and VLDL production by insulin. Diabetes 53:2529-2534

9. Obici S, Feng Z, Tan J, Liu L, Karkanias G, Rossetti L (2001) Central melanocortin receptors regulate insulin action. J Clin Invest 108:1079-1085

10. Mizuno TM, Kelley KA, Pasinetti GM, Roberts JL, Mobbs CV (2003) Transgenic neuronal expression of proopiomelanocortin attenuates hyperphagic response to fasting and reverses metabolic impairments in leptin-deficient obese mice. Diabetes 52:2675-2683

11. Fan W, Dinulescu DM, Butler AA, Zhou J, Marks DL, Cone RD (2000) The central melanocortin system can directly regulate serum insulin levels. Endocrinology 141:3072-3079

12. Vaisse C, Clement K, Guy-Grand B, Froguel P (1998) A frameshift mutation in human MC4R is associated with a dominant form of obesity. Nat Genet 20:113-114

13. Yeo GS, Farooqi IS, Aminian S, Halsall DJ, Stanhope RG, O'Rahilly S (1998) A frameshift mutation in MC4R associated with dominantly inherited human obesity. Nat Genet 20:111112

14. Fan W, Boston BA, Kesterson RA, Hruby VJ, Cone RD (1997) Role of melanocortinergic neurons in feeding and the agouti obesity syndrome. Nature 385:165-168

15. Schioth HB, Muceniece R, Mutulis F et al (1997) Selectivity of cyclic [D-Nal7] and [D-Phe7] substituted MSH analogues for the melanocortin receptor subtypes. Peptides 18:1009-1013

16. Paxinos G, Franklin K (1997) The mouse brain in stereotaxic coordinates. Academic, San Diego

17. Murphy B, Nunes CN, Ronan JJ, Hanaway M, Fairhurst AM, Mellin TN (2000) Centrally administered MTII affects feeding, drinking, temperature, and activity in the Sprague-Dawley rat. J Appl Physiol 89:273-282

18. Voshol PJ, Jong MC, Dahlmans VE et al (2001) In musclespecific lipoprotein lipase-overexpressing mice, muscle triglyceride content is increased without inhibition of insulin-stimulated whole-body and muscle-specific glucose uptake. Diabetes 50:25852590

19. van den Hoek AM, Heijboer AC, Corssmit EP et al (2004) PYY3-36 reinforces insulin action on glucose disposal in mice fed a high-fat diet. Diabetes 53:1949-1952

20. Chomczynski P, Sacchi N (1987) Single-step method of RNA isolation by acid guanidium thiocyanate-phenol-chloroform extraction. Anal Biochem 162:156-159

21. Haynes WG, Morgan DA, Djalali A, Sivitz WI, Mark AL (1999) Interactions between the melanocortin system and leptin in control of sympathetic nerve traffic. Hypertension 33:542 547

22. Satoh N, Ogawa Y, Katsuura G et al (1998) Satiety effect and sympathetic activation of leptin are mediated by hypothalamic melanocortin system. Neurosci Lett 249:107-110

23. Nonogaki K (2000) New insights into sympathetic regulation of glucose and fat metabolism. Diabetologia 43:533-549

24. Brindley DN (1995) Role of glucocorticoids and fatty acids in the impairment of lipid metabolism observed in the metabolic syndrome. Int J Obes Relat Metab Disord 19 [Suppl 1]:S69S75 
25. Lu XY, Barsh GS, Akil H, Watson SJ (2003) Interaction between alpha-melanocyte-stimulating hormone and corticotropin-releasing hormone in the regulation of feeding and hypothalamo-pituitary-adrenal responses. J Neurosci 23:78637872

26. Corssmit EP, Stouthard JM, Romijn JA, Endert E, Sauerwein HP (1994) Sex differences in the adaptation of glucose metabolism to short-term fasting: effects of oral contraceptives. Metabolism 43:1503-1508

27. Corssmit EP, Van Lanschot JJ, Romijn JA, Endert E, Sauerwein HP (1995) Truncal vagotomy does not affect postabsorptive glucose metabolism in humans. J Appl Physiol 79:97-101
28. Pierroz DD, Ziotopoulou M, Ungsunan L, Moschos S, Flier JS, Mantzoros CS (2002) Effects of acute and chronic administration of the melanocortin agonist MTII in mice with diet-induced obesity. Diabetes 51:1337-1345

29. Jonsson L, Skarphedinsson JO, Skuladottir GV, Watanobe H, Schioth HB (2002) Food conversion is transiently affected during 4-week chronic administration of melanocortin agonist and antagonist in rats. J Endocrinol 173:517-523 